\title{
BATHING WATERS IN POLAND - ISSUES OF ORGANIZATION AND SUPERVISION OF BATHING AREAS IN THE LIGHT OF CHANGES IN THE WATER LAW
}

\author{
Ewa Kaznowska, Michał Wasilewicz
}

Faculty of Civil and Envirnonmental Engineering, Warsaw University of Life Sciences-SGGW, Nowoursynowska 159, 02-787 Warsaw

\begin{abstract}
Aim of the study

The aim of the paper is to assess changes in organization and supervision of bathing areas and sites occasionally used for bathing in Poland after the implementation of the Bathing Water Directive 2006/7/EC.

Material and methods

The study is based on the law regulation published in the Journal of Laws and Polish Monitor - Official Journals of the Republic of Poland). Also, Chief Sanitary Inspectorate annual reports and Bathing Web Service (www.sk.gis.gov.pl) were used in the investigation. The analysis of the number of bathing waters covers the period of 2010-2019, while the quality of bathing waters was analysed in the period of 2014-2018.
\end{abstract}

\begin{abstract}
Results and conclusions
In terms of quality, the highest number of evaluations of water unsuitability for bathing in 2011-2018 was given due to cyanobacteria blooms (the highest in 2018).

The assessment of water quality carried out in 2018 (being the mean from 2015-2018), similarly to the assessment from 2014 (the mean from 2011-2014), indicated the excellent quality of more than $70 \%$ of bathing waters, about $10 \%$ were sufficient and only 3 inland bathing waters $(1 \%)$ were found to have poor quality.

According to data from 2018, Poland ranks 22nd among EU countries in terms of the number of bathing waters with excellent water quality. Despite the constantly growing tendency to improve the quality of bathing waters, when compared to other EU countries, Poland still lacks a lot to the European average of $85 \%$ of bathing areas with excellent water quality.
\end{abstract}

Keywords: water quality, Water Law Act, Bathing Water Directive 2006/7/EC, bathing area

\section{INTRODUCTION}

The obligation to create and implement a bathing water management system results from Directive 2006/7/EC of the European Parliament and of the Council of 15th February 2006 on the management of bathing water quality, the primary purpose of which is to preserve and improve the environment and to protect human health (NIK 2014). The directive announced in 2006 revokes the previous one (Directive76/160/EEC), which was grounded on the state of knowledge and experience of the early 1970s. The current directive has been developed on the basis of available scientific and technical knowledge, including the most reliable indicators for controlling and classifying bathing water quality. The directive also

凶e-mail:ewa_kaznowska@sggw.edu.pl 
puts a stronger emphasis on publicising information on bathing water quality effectively and consistently across the entire European Union. The directive also intends to ensure a high level of water protection (in respect of protecting the environment and human health) through a system for determining bathing water profiles for better risk recognition in quality management. The EU Member States were given time to fully implement the Directive by 2015 , and for the first time, the actions pursuant to it could have been taken before the start of the bathing season after 24th March 2008. The new regulations on supervision of bathing waters required an amendment to the existing provisions in the Water Law. Poland with its accession to the European Union in 2004 had to implement European standards, but it should be emphasized that already in 1919 the issues of clean water, including 'folk baths', were included in the Polish Basic Sanitary Act of 19 July 1919 (GIS 2018).

The aim of the work is to assess changes in the organization and supervision of bathing waters in Poland that have occurred as a result of the implementation of the 2006 directive into Polish legislation in the first decade since its implementation. The analysis also covers the results of classification of bathing water quality in Poland against the background of other EU countries.

\section{SUBJECT OF RESEARCH}

\section{Implementation of Directive 2006/7/EC in the Polish legal order}

Legal regulations resulting from the implementation of Directive 2006/7/EC, regarding the management of bathing water quality, have been amended in Polish legislation as a result of the publication of the Act of 4th March 2010. (Act of 4th March 2010 amending the Act - Water Law. Journal of Laws of 2010 No. 44, item 253). The Act entered into force on 1 January 2011 and repealed the Regulation of the Minister of Health of 16th October 2002. (Regulation of the Minister of Health of 16th October 2002 on the requirements to be met by bathing waters. Journal of Law of 2002 No. 183 item 1530). The most important changes included: redefining the notion of bathing waters, defining the duties of bathing waters organisers, as well as the responsibilities of public administration and the State
Sanitary Inspection. In the years following 2010, the provisions in the Water Law concerning bathing waters were subject to several changes, and their existing wording is contained in the amendment of the Water Law announced on 20th July 2017 (Act of 20th July 2017. Journal of Law of 2018 item 2268 as amended).

\section{Bathing waters}

As defined in Article 9 section 1 point 5a of the Act of 4th March 2010 (amending the Act - Water Law), bathing waters are a designated by the resolution of a municipal council, separate and marked part of surface waters, used by a large number of bathers, as defined in the resolution of a municipal council on a list of bathing waters, provided that no permanent bathing ban has been issued in respect of this bathing area (see: Fig.1, 2). Bathing waters are not: swimming pools; spa pools; closed bodies of water subject to purification or used for therapeutic purposes; artificial closed bodies of water separated from surface waters and groundwater. In the following years, the definition of bathing waters has not changed and still applies in the above wording (Article 16 - Act of 20th July 2017, Water Law). Since the entry into force of the Act of 4th March 2010, the procedure for preparing a draft resolution by the relevant public administration (commune head, mayor) covering the list of planned bathing waters takes place every year for a given bathing season. In the 2011-2017 period the project had to be submitted by 31 st May, while from 2018 (as a result of the provisions of the new Water Law of 2017) within a shorter term - by 20th May. The list of bathing areas is prepared after the organizers' applications are considered. Applications are submitted by 31 st December in the year preceding the bathing season in which the bathing beach is to be open (Article 37 section 3 of the Act of 20th July 2017. Water Law. Journal of Laws of 2018, item 2268, as amended) The draft resolution with a list of organized bathing areas is made public and is reviewed by relevant entities responsible for bathing water quality: especially by the voivodeship environmental protection inspector (WIOŚ) and the county state sanitary inspector (PPIS). The municipal council approves the draft resolution designating bathing areas in a given municipality or within Polish maritime areas adjacent to the municipality, in a given bathing season, in a period between 1st June and 

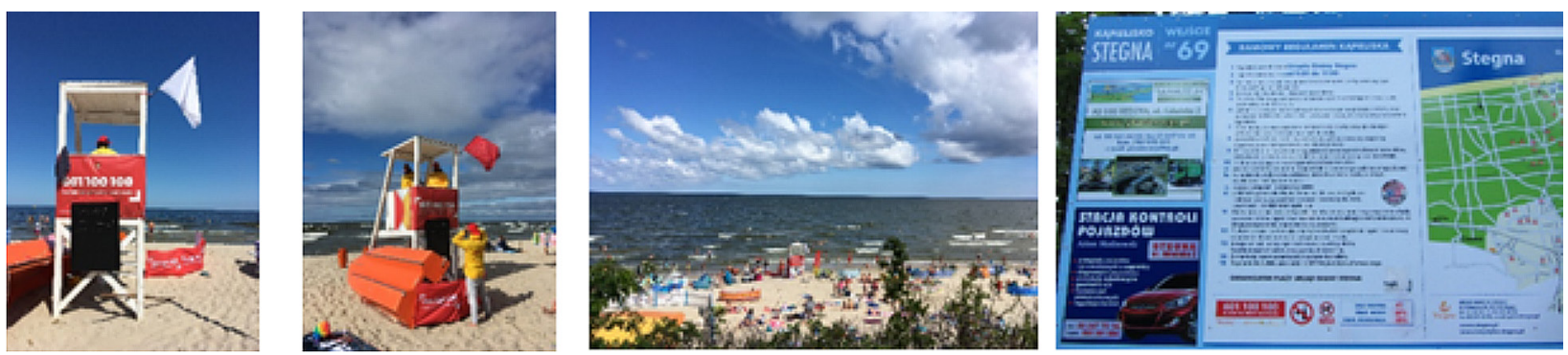

Fig.1. The Stegna bathing area, July 2019
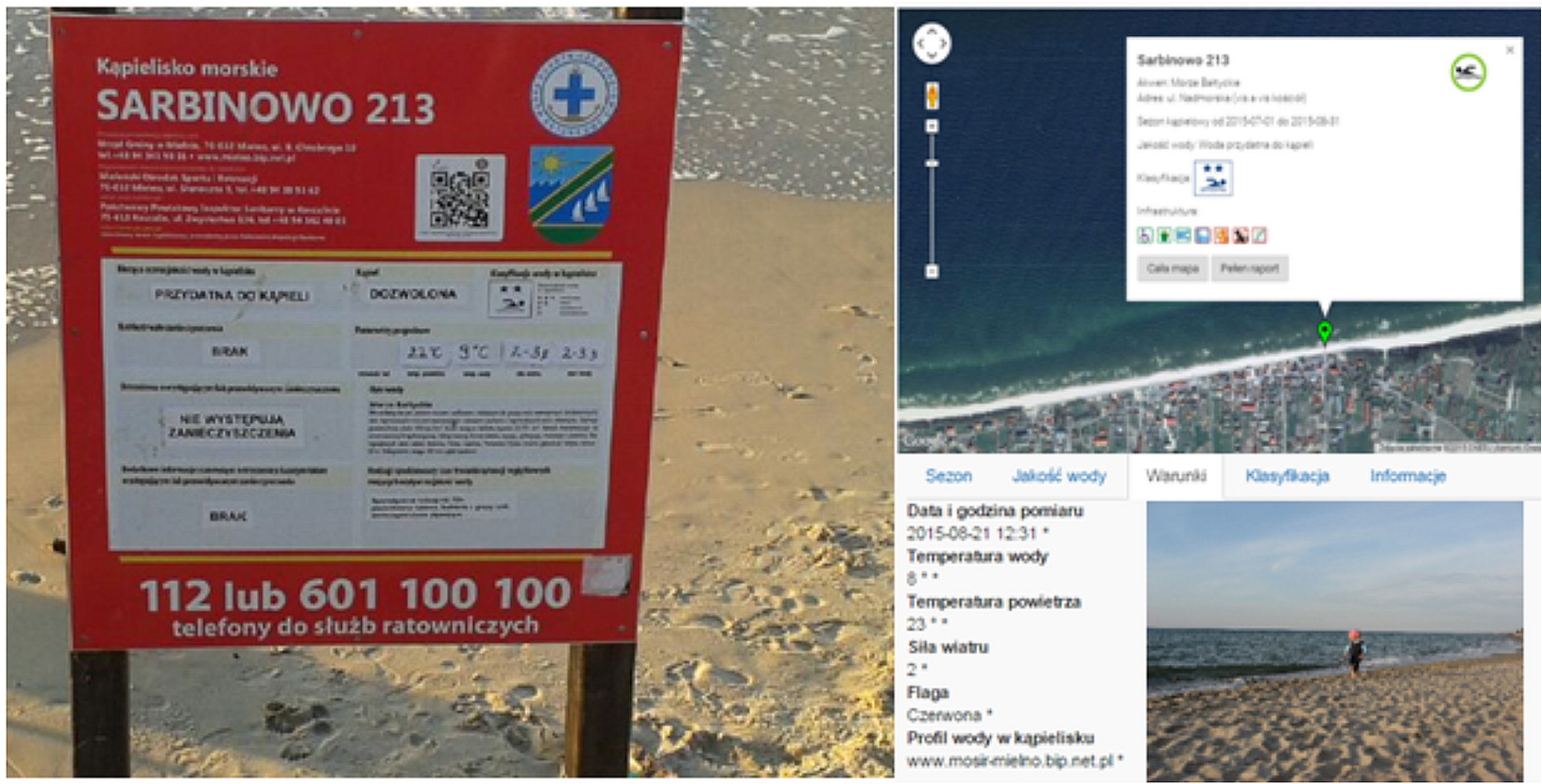

Fig. 2. The Sarbinowo bathing area, August 2015

30th September (Article 37 section 1 of the Act of 20 th July 2017, Law Journal of Laws of 2018, item 2268, as amended). In the years 2011-2017, the bathing season was announced shorter and covered a period between 15th June and 30th September (Article 34a section 1 of the Act of 4th March 2010 amending the Act - Water Law. Journal of Laws of 2010 No. 44, item 253).

According to the first provisions after the implementation of the directive, the organizer of a bathing beach could be a natural person, a legal person or an organizational unit without legal personality who undertook to organize a bathing beach and obtained the consent of the owner of waters and the adjacent area or who runs the bathing beach (Article 9 section 1 point $7 \mathrm{a}$ of the Act of 4th March 2010). However, the definition of bathing waters organizer in the new Water Law of 2017 in Article 16 is as follows: a natural person, legal person or an organizational unit without legal personality who runs a bathing beach or has undertaken to organize a bathing beach. The change in the definition of the bathing waters organizer concerns the presumption of having a consent of an owner of waters and the adjacent area to organize bathing waters at a given site. The legislator imposed on the bathing waters organizer a number of obligations set out in Table 1. One of the most important is 
to prepare a water profile understood as a set of data and information on the physical, geographical and hydrological features of bathing waters and surface waters, having an impact on their quality, along with the identification and assessment of the causes of pollution that may adversely affect the quality of bathing waters and the state of health of its users (Art. 16, Water Law of 20th July 2017). Bathing water profiles are complicated documents, mainly due to their large scope and diverse subjects, and their elaboration re- quires collecting (for a fee) and processing data from many institutions. The profile is updated depending on the results of bathing water classification and changes in the development of bathing waters and adjacent areas, which may affect the water quality. These tasks may be associated with additional costs incurred by a bathing waters organizer, in addition to those already spent on obtaining information for preparing its profiles (Skotak et al., 2012).

Table 1. Obligations of bathing waters organizer and an organizer of a site used for bathing/site occasionally used for bathing (Chief Sanitary Inspectorate) 2017, The Act of 4th March 2010 - amending the Water Law; The Act of 20th July 2017 Water Law)

\section{Bathing waters}

1. organizes a bathing beach and maintains its infrastructure;

2. proposes to designate a bathing area by a resolution of a commune head, mayor or city president and to include bathing areas operating within the municipality in the register;

3. draws up a bathing waters profile, updates it and submits it to the commune head, mayor or city president;

4. marks the bathing waters;

5. conducts internal water quality control:

- sets up together with the relevant sanitary inspector the schedule of water sampling for laboratory tests (usually when a bathing season exceeds 8 weeks, the first sample is taken not earlier than 10 days before the opening of the bathing season and no less than three samples are taken during the bathing season, when bathing waters operate so that the interval between tests is no longer than a month (i.e. at least once a month);

- takes samples for water testing at points agreed with the relevant sanitary inspector;

- takes additional bathing water samples within 7 days after cessation of short-term pollution;

- commissions testing the water quality to laboratories authorized by law to perform water tests (laboratories of the State Sanitary Inspection or other laboratories approved by the bodies of the State Sanitary Inspection);

- immediately submits the results of water tests to the relevant sanitary inspector for ongoing water quality assessment;

- informs the relevant sanitary inspector about any changes that may affect the bathing water quality and about the suspension of bathing waters test schedule;

- informs bathers about the quality of bathing water and the recommendations of the bodies of the State Sanitary Inspection;

6. identifies the cause of possible water pollution and takes measures to protect human health and improve water quality;

7. enters and updates data on bathing waters on the online Bathing Website.
Site used for bathing

1. organizes the site used for bathing;

2. carries out a water quality test not earlier than 14 days before the day of its commencement and at least once during its functioning (i.e. at least once every 2 months in the bathing season, usually lasting for the summer months);

3. performs a water quality test for visually identified pollution that may have an adverse effect on the water quality and pose a health risk to bathers;

4. marks the site used for bathing;

Site occasionally used for bathing

1. organizes the site occasionally used for bathing;

2. performs a water quality test not earlier than 10 days before the opening the site and at least once during its operation (i.e. at least once a month, assuming that the place is open in one of the bathing season months).

3. performs a water quality test for visually identified pollution that may have an adverse effect on the water quality and pose a health risk to bathers;

4. marks the site occasionally used for bathing;

Own study: according to Chief Sanitary Inspectorate 2017, The Act of 4th March 2010 - amending the Water Law; The Act of 20th July 2017- Water Law 


\section{Site used for bathing}

Directive 2006/7/EC of the European Parliament and of the Council of 15th February 2006 concerning the management of bathing water quality provides for the establishment of bathing waters only. However, in the Polish legislation, due to the need of organizing a form of recreation related to bathing, which could not be subject to a relatively time-consuming procedure of establishing bathing waters, the notion of a site used for bathing was introduced. This solution was to ensure the safety of bathing in exceptional situations, e.g. sudden organization of competitions, scout or other camps, seasonal resorts or agritourism farms. A site used for bathing meant a separated and marked fragment of surface waters, which was not a bathing area but used for bathing (Art.9 sec. 1 item $5 \mathrm{c}$ of the Act of 4th March 2010 - amending the Water Law). The Legislator has imposed lesser requirements on the organizer of a site used for bathing (see: Table 1) than on the organizer of a bathing area. It should be noted after Skotak et al. (2012) that the division into bathing waters and sites used for bathing introduced in Poland is not reflected in the provisions of Directive 2006/7/EC and may have very serious consequences in the future in the aspect of public health protection (safety of bathers). Initially, sites used for bathing (see: Fig. 3) were supposed to be developed and transformed into bathing areas out of organizers' will and capabilities, but in practice it turned out that organizers closed bathing areas and transform them into sites used for bathing that do not meet high sanitary criteria (GIS, 2017). This form of abuse of recreation organization could be identified, because apart from exceptional situations, it was used to circumvent legal regulations for bathing waters (Król, 2019). According to the NIK (Supreme Audit Office) (2014), relinquishing from organizing the above-mentioned facilities was caused by high maintenance costs, difficulties in employing qualified lifeguards, as well as the need to provide rescue equipment and medical facilities. Concerns presented by Skotak et al. in 2012 that a significant scope of duties imposed on bathing waters organizers, along with substantive and financial requirements will lead to a drastic decrease in the number of bathing areas in Poland (as a result of their transformation into much cheaper sites used for bathing) proved to be reasonable.

\section{Site occasionally used for bathing}

In order to strengthen the health safety of people using existing sites used for bathing, the Chief Sanitary Inspectorate proposed to change the definition from 'site
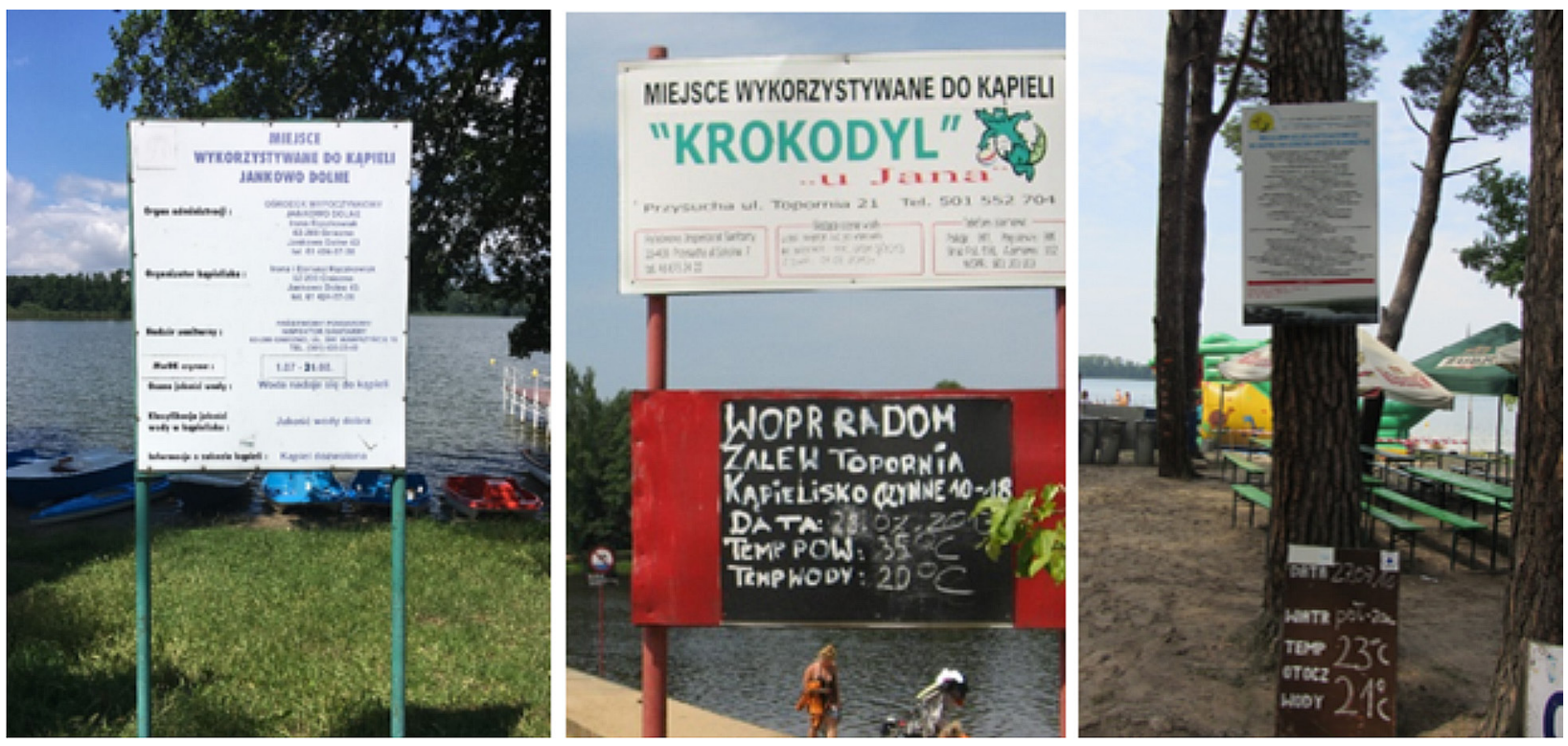

Fig. 3. Site used for bathing: Jankowo Dolne July 2017, Przysucha July 2013, Mierzyn July 2016 
used for bathing' to 'site occasional used for bathing' so that the organizers, in situations where they can create a bathing beach, would not repeal from this duty. This change was introduced to the draft of the new Water Law in Poland from 2017. In accordance with the Act of 20th July 2017, Water Law, from 1st January 2018, except for bathing waters, there may only be sites occasionally used for bathing. The sites occasionally used for bathing are established with the consent of a municipal council as a resolution (after submitting an appropriate application by the organizer of such a site). The most important modification is the introduction of a fixed period in which sites occasionally used for bathing can function that cannot be longer than 30 days in a calendar year (Art. $39 \mathrm{sec}$. 1 of the Act of 20th July 2017, Water Law, Journal of Laws of 2018, item 2268, as amended). According to Król (2019), the change covers also the alignment of requirements for the minimum number of water quality tests for bathing areas and sites occasionally used for bathing, thus ensuring equal health requirements for both forms of recreation related to bathing (the interval between water sampling does not exceed month). The changes were intended to force an increase in the number of bathing areas, and a decrease in the number of sites occasionally used for bathing. The bathing season in Poland can last from 1st June to 30th September, and limit it to 30 days would be unprofitable for the organisers of sites occasionally used for bathing and inconvenient for users. In the first bathing season after the modifications in 2018, sites occasionally used for bathing only functioned in July, either only in August, or for ten three-day weekends during the summer (GIS, 2018b).

Implementing regulations for the Act of 4th March 2010 - amending the Water Law, concerning the scope of operation and supervision of bathing areas and sites used for bathing were issued by the Minister of Health and the Minister of the Environment in 2011 and in later years (Regulation of the Minister of Health, 2018, 2019).

\section{Bathing water quality assessment}

The most important element of bathing supervision is the water quality assessment, carried out since 2011 in accordance with the Regulation of the Minister of Health of 8th April 2011 (Journal of Laws No. 86, item 478) and its subsequent amendment in 2019 (Regulation of the Minister of Health of 17th January 2019). The current assessment on the fitness for use of bathing waters should be carried out for both bathing areas and sites used for bathing (sites occasionally used for bathing). On the other hand, bathing areas undergo also a seasonal and four-year evaluation (Skotak et al., 2012). The current evaluation should be based on the reports of water quality tests. It allows to determine the water quality and the possibly of withdrawing bathing waters from use in case of abnormal microbiological results or cyanobacteria blooms. Seasonal assessment is made at the end of each bathing season on the basis of water quality test reports and provides a brief descriptive summary of any management measures taken by the organiser, municipality authorities, the authorities of the State Sanitary Inspection (PIS) and other interested parties. Whereas four-year assessment (classification) includes the last and three preceding bathing seasons (WSSE SZCZECIN, 2016).

Water standards that are to be met in bathing areas and sites used for bathing, set out in Annex 1 of the Regulation of 2011, were significantly simplified, when compared to previous legal regulations contained in the Regulation of the Minister of Health of 2002 (Regulation of the Minister of Health of 16th October 2002, Journal of Laws of 2002 No. 183 item 1530). The scope of the performed tests was limited to only two microbiological indicators: the number of Enterococci and E. coli in $100 \mathrm{ml}$ of water and visual assessment (cyanobacteria blooms, reproduction of macroalgae and phytoplankton and the presence of physical impurities in water), while maintaining the basic objective to gather information about a possible safety risk for bathers as fast as possible. The ongoing assessments issued by the State Sanitary Inspection during a bathing season permit $\leq 400 \mathrm{cfu} / 100 \mathrm{ml}$ or $\mathrm{NPL} / 100 \mathrm{ml}$ of Enterococci and $\leq 1000 \mathrm{cfu} / 100 \mathrm{ml}$ or NPL/100ml of E.coli (Regulation of the Minister of Health of 17th January 2019 on the supervision of the quality of bathing waters and sites occasionally used for bathing (Journal of Laws, item 255). Until 2010, under the Regulation of the Minister of Health of 2002, supervision over bathing water quality was financed entirely from the state budget and implemented by employees of sanitary and epidemiological 
stations. The supervision covered almost all known bathing areas and sites traditionally used for bathing. And the number of mandatory parameters of bathing water quality was much higher (Skotak et al., 2012). In order to check the utility values of surface waters in regard to their use for the organization of bathing waters, a number of indicators were analysed: $\mathrm{pH}$ values, total suspensions, dissolved oxygen, ammonium and nitrate nitrogen and phosphates (Kanownik and Kowalik, 2008).

According to Zimoch and Paciej (2013), simplifying the visual assessment was necessary because it is currently done by the owners of water recreation facilities as part of internal control (see: Table 1). Inspection authority - National Sanitary Inspection - conducts an official quality control of water in bathing areas and in sites used for bathing only once before the season and when an organiser notices deterioration of water quality. The organizer of a bathing area or a site used for bathing, after noticing the deterioration of water condition, must inform a relevant County State Sanitary Inspector (PSSE), who only then is obliged to conduct an official control in order to assess the bathing water quality. Zimoch and Paciej (2013) emphasize that in order to issue a comprehensive seasonal assessment of the quality of bathing water, in accordance with the Regulation of the Minister of Health of 2011 (Regulation of the Minister of Health of 8th April 2011 on supervision of bathing water quality and Journal of Laws No. 86, item 478) the bodies of the State Sanitary Inspection base on water quality tests carried out as part of an internal control by a bathing facility organizer and on the basis of own results obtained from official control.

\section{Bathing water quality classification}

Act of 18th July 2001, Water law introduced a classification, which allocates appropriate classes to bathing water according to its properties. According to the guidelines of the 2006 directive (Directive 2006/7/EC of the European Parliament and of the Council of 15th February 2006 concerning the management of bathing water quality) bathing water classification is determined on the basis of four-year assessments instead of previous annual evaluations. This means that the classification introduced by the directive from 2006 is less susceptible to bad weather conditions or unusual events. To classify its water quality, the bathing area must have an appropriate data set containing at least 16 samples (for bathing beaches with bathing seasons not exceeding 8 weeks) from four bathing seasons. The procedure for classifying bathing areas is set out first in the Regulation of the Minister of Health of 8th April 2011, and currently in the Regulation of the Minister of Health of 17th January 2019. Bathing water can be classified as 'excellent', 'good', 'sufficient', 'poor' - the microbiological requirements for a given water classification are presented in Table 2 .

Table 2. Bathing water classification (according to the Regulation of the Minister of Health of 17th January 2019 on the supervision of water quality in bathing areas and sites occasionally used for bathing. Journal of Laws item 255)

\begin{tabular}{|c|c|c|c|c|}
\hline No. & Parameter & Excellent & Good & Sufficient \\
\hline \multicolumn{5}{|c|}{ Inland water } \\
\hline 1 & $\begin{array}{c}\text { Enterococcus } \\
\text { (units/100ml } \\
\text { or MPN/100ml) }\end{array}$ & $200^{*}$ & $400 *$ & $330 * *$ \\
\hline 2 & $\begin{array}{l}\text { Escherichia coli } \\
\quad \text { (units/100ml } \\
\text { or MPN/100ml) }\end{array}$ & $500^{*}$ & $1000^{*}$ & $900 * *$ \\
\hline \multicolumn{5}{|c|}{ Coastal and transitional water } \\
\hline 1 & $\begin{array}{c}\text { Enterococcus } \\
\text { (units/100ml } \\
\text { or MPN/100ml) }\end{array}$ & $100^{*}$ & $200^{*}$ & $185^{* *}$ \\
\hline 2 & $\begin{array}{l}\text { Escherichia coli } \\
\text { (units/100ml } \\
\text { or MPN/100ml) }\end{array}$ & $250^{*}$ & $500^{*}$ & $500 * *$ \\
\hline
\end{tabular}

* based upon a 95-percentile evaluation

** based upon a 90-percentile evaluation

\section{Bathing website}

The bathing website was created for the purpose of meeting the requirements of the 2006 Directive, as well as to allow the public to be actively informed about the current condition of bathing water quality in a given bathing season, and in particular about a ban on bathing due to water quality (see: Fig. 4). According to the provisions of Article 6 point 2 of the Act of 4th March 2010 amending the Water Law Act, the bodies of the State Sanitary Inspection were obliged to 


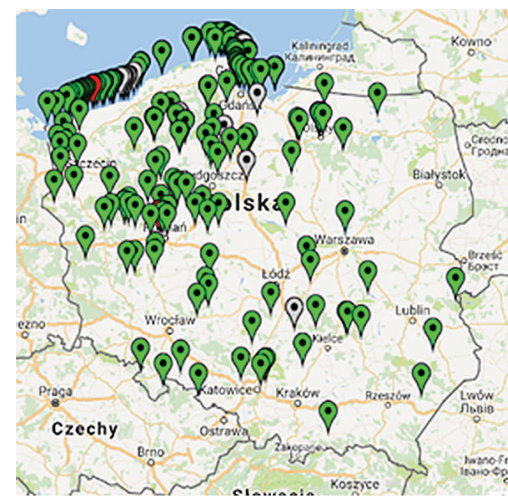

a)

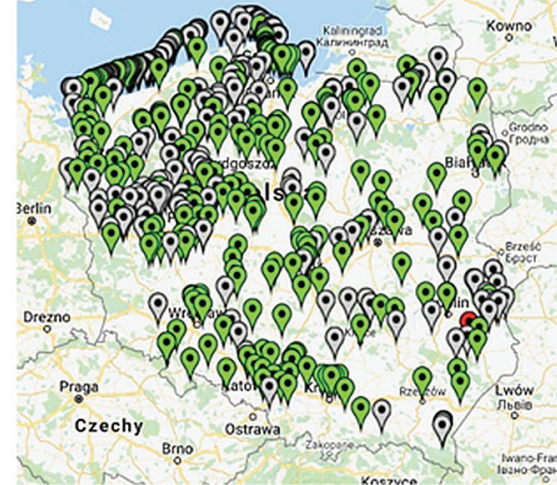

b)

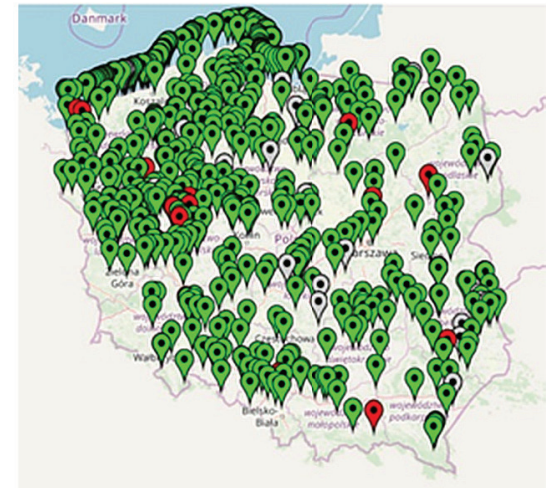

c)

Fig. 4. The bathing waters map, scan from 31th August 2017 (a); 25th June 2018 (b); 28th August 2019 (c)

operate the bathing website since the bathing season in 2013, at the website of the Main Sanitary Inspectorate (GIS) (http://sk.gis.gov.pl/). However, since 2008 the Chief Sanitary Inspectorate has run a bathing website based on data from sixteen Voivodeship Sanitary and Epidemiological Stations, actively disseminating information on the quality of bathing waters and available bathing infrastructure.

\section{MATERIALS AND METHODS}

Legal acts published by the Parliament of the Republic of Poland in the Internet System of Legal Acts (ISAP) were used in order to present the issues of bathing organization in the Polish legal order as a result of the implementation of the provisions of Directive 2006/7/EC of the European Parliament and of the Council of 15th February 2006 on bathing water quality management. The analysis also included the supervision of bathing waters and bathing water quality in the last 10 years (2010-2019), in which the provisions of the 2006 Directive (Directive 2006/7/EC of the European Parliament and of the Council of February 2006 concerning the management of bathing water quality and repealing Directive 76/160/EEC) were in force since the bathing season in 2011. On the basis of the data published in the annual reports of the Chief Sanitary Inspectorate (GIS) on the sanitation status of the country and data posted on the GIS website and bathing website (http://sk.gis.gov.pl/) and the annual reports of the European Environment Agency (EEA) and the European Commission on bathing water quality, changes were made: in the organization of bathing areas in Poland, their number and locations, their supervision and in the results of the water quality classification against the other countries of the European Union.

The analysis of the results of the classification of bathing water quality in Poland covers the period 2014-2018, as the first four-year assessment of bathing areas (reported for the bathing season 2011) took place in 2015. On the other hand, the 'last period of bathing assessment' - four bathing seasons (2016-2019) - was used to present the results of current bathing water quality assessments on microbiological indicators of sanitary condition (E. Coli, Enterococces) and the dates of the cyanobacteria blooms. Five bathing areas were selected in two voivodeships with the highest number of bathing areas (West Pomeranian and Pomeranian Voivodeships). Bathing beaches: Grzybowo (West Pomeranian Voivodeship, Kołobrzeski County), Sarbinowo 213 (West Pomeranian Voivodeship, Koszalin County), Jastrzębia Góra 23 (Pomeranian Voivodeship, Pucki County) are located in the Baltic Sea; and bathing beaches: Gdańsk Stogi (Pomeranian Voivodeship, Gdańsk County), Stegna II (Pomeranian Voivodeship, Novodworski County) are located in Gdańsk Bay.

The source material on the results of current water quality assessments, based on microbiological requirements and visual water observation results, comes from the bathing service (http://sk.gis.gov.pl/). 


\section{RESULTS DISCUSSION}

\section{Number of bathing areas and sites used for bathing}

In 2010 , in the last season before the changes were introduced to the organisation of bathing areas resulting from the implementation of the 2006 Directive (Directive 2006/7/EC of the European Parliament and of the Council of 15th February 2006 concerning the management of bathing water quality and repealing Directive 76/160/EEC) 1229 bathing areas remained in the register of the State Sanitary Inspection. 1198 bathing areas were covered by sanitary supervision: 1081 inland areas (out of 1112 in the records), 117 marine. Out of 1198 bathing areas inspected: 369 were organized facilities and 829 were unorganized, traditionally used for bathing by the populace (GIS 2010). In previous years, according to Skotak et al. (2012), the number of bathing areas supervised by the State Sanitary Inspection authority decreased annually, in 2007: 1377; in 2008: 1297; in 2009: 1246. Skotak et al. (2012) claim that this situation is caused by decreasing number of bathing areas reported by the organizers for a supervision of the State Sanitary Inspection and by the interpretation of the term 'significant' number of bathers that was in force previously in the definition of bathing waters (Article 9 sec. 1 of the Act of 18th July 2001, Water law, according to which bathing waters mean flowing or stagnant waters or parts thereof and marine waters in which bathing is explicitly authorised or not prohibited and is traditionally carried out by a significant number of bathers). If the number of bathers in a given area was 'significant' then, according to the regulations in force at that time, water quality should be monitored in such a place. As a result, sites usually used for bathing were gradually excluded from supervision, provoking wild bathing areas, i.e. unmarked places, not covered by the supervision of water rescue services and where, according to the State Sanitary Inspection authorities, the number of bathers was not significant.

Introduction of the requirements of the new provisions of the 2006 Directive regarding the management of bathing water quality ended up cutting the amount of bathing waters in Poland from nearly 1,000 to slightly over 200 (see: Table 3). The directive has significantly changed its approach to the way bathing water quality is monitored (GIS, 2011). In 2011, i.e. the first year after coming into force of its entries, the number of bathing areas in Poland decreased more than five times compared to 2010 (see: Table 3) and totalled 220. In 2012, 221 bathing areas were set up across the country. In the following years, the number of organized bathing waters decreased and amounted to 205 beaches in 2017 (see: Table 3).

Compared to bathing areas, the number of sites used for bathing during the years 2011-2017 was still high, 4 times higher than bathing waters (see: Table 3 ),

Table 3. Number of bathing water areas and sites used for bathing/ sites occasionally used for bathing between 2010 and 2019

\begin{tabular}{lcccccccccc}
\hline \multicolumn{1}{c}{ Years } & 2010 & 2011 & 2012 & 2013 & 2014 & 2015 & 2016 & 2017 & 2018 & $2019 *$ \\
\hline Applicable law & I & II & II & II & II & II & II & II & III & III \\
\hline Bathing waters & 1229 & 220 & 221 & 204 & 201 & 197 & 201 & 205 & 483 & 607 \\
\hline Site used for bathing & & n/a & 845 & 845 & 897 & 886 & 861 & 838 & & 376 \\
\hline
\end{tabular}

Explanatory notes: n/a no data available; * raw data from the bathing area website and GIS website

I - Regulation of the Minister of Health of 16th October 2002 on the requirements to be met by bathing waters. Journal of Laws of 2002 No. 183 , item 1530

II - Act of 4th March 2010 (Journal of Laws No. 44 item 253) on the amendment to the Water Law Act of 18th July 2001. (Journal of Laws of 2005, No. 239, item 2019) together with Regulations of the Minister of the Environment and the Minister of Health III - Act of 20th July 2017. Water Law (Journal of Laws of 2018, item 2268, of 2019, item 125, 534.1495, 2170) together with Regulations of the Minister of Health

own study: according to GIS reports (2010-2019); GIS bathing waters website 
which is related to the fact that the regulations set definitely higher requirements for the bathing waters organizer who was to ensure comprehensive supervision of water quality. It was evident that the strong measures taken to improve water quality and protect health at sites used for bathing did not have any real effects, contrary to the legislator's original intention (GIS, 2015). Therefore, in the 2018 bathing season, for the first time sites occasionally used for bathing were introduced instead of sites used for bathing, to strengthen the health security of everyone enjoying these beaches. Change in the Water Law of 20th July 2017 (Journal of Laws, item 1566, as amended), which shortened the acceptable time of operation of sites occasionally used for bathing to 30 days of a calendar year, brought a significant decrease in the number of such sites, by more than half in the first year after its introduction (see: Table 3). The amendment to the Water Law Act had a positive impact on the increase in the number of bathing areas (2.5 times compared to previous years) recorded in $2018-483$, and in the next bathing season in 2019 as much as 607 (3 times more than in 2016) (see: Table 3, Fig. 4). There was an evident decrease in the sites occasionally used for bathing, from 376 in 2018 to 331 in 2019 (see: Table 3). However, in order to enable the facility to operate for more than 30 days in a calendar year (as anticipated by the legis- lator), some organizers have allocated more than one site occasionally used for bathing at the same body of water (reservoir, pond, excavation) and with the same address. The difference was in the name of the site, sometimes with an additional term, e.g. 'I', II 'or 'eastern part', 'western part' (GIS 2019b - MOWK list). In 2019, the organizers of sites occasionally used for bathing have employed this solution in about 40 cases on over 300 facilities, allowing such 'bathing waters' to operate for a total of 60 days (e.g. in July 'beach I' and in August 'beach II') (GIS 2019b - MOWK list).

\section{Location of bathing waters and sites occasionally used for bathing}

In 2010 (before the 2006 Directive was introduced), $90 \%$ of all bathing areas were 'inland bathing waters' (inland surface waters), and only $10 \%$ were 'sea bathing waters' (coastal and transitional waters) (see: Fig. 5). In the first year of the provisions of the 2006 Directive being in force (Directive 2006/7/EC of the European Parliament and of the Council of 15th February 2006 concerning the management of bathing water quality and repealing Directive 76/160/EEC), in 2011 the ratio of inland bathing waters to sea bathing waters has changed significantly: $60 \%$ of all bathing areas were inland bathing waters, and $40 \%$ were sea bathing (see: Fig. 5). Out of 220 bathing areas created across

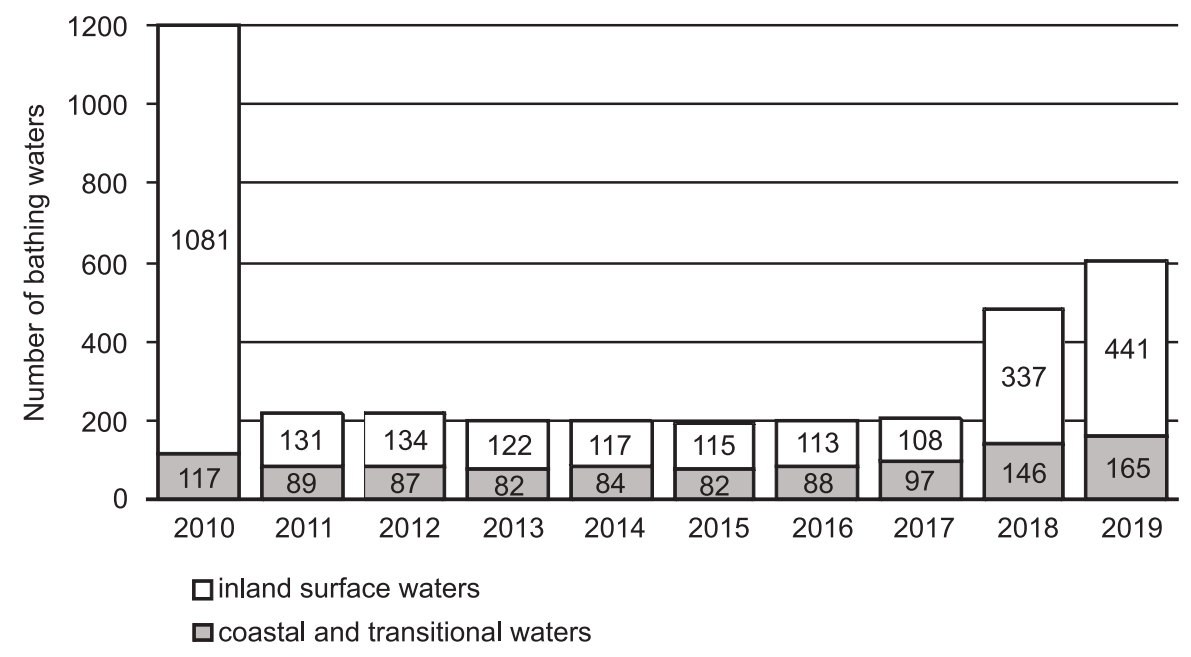

Fig.5. Number of bathing waters (inland water, coastal and transitional water) supervised by the State Sanitary Inspection in years 2010-2019

Source: own study, according to GIS reports (2010-2019), the GIS bathing waters website 
the country in 2011, as many as 70 were in the Pomorskie Voivodeship (GIS, 2011). However, no bathing area was organized in the Małopolskie Voivodeship, despite the fact that a year earlier according to PIS records there were 44 in this area (GIS, 2010). Lesser Poland (Małopolskie Voivodeship) is characterized by a small number of water reservoirs suitable for recreation. One of them is the Kryspinów reservoir created as part of land reclamation after sand exploitation. This is the only such large water reservoir in the vicinity of Kraków, eagerly visited by residents, which is why its microbiological quality is extremely important (Chmiel, Maciag 2010). Also, the Małopolskie Voivodship is the second, just behind Mazowieckie, most visited by tourists region in Poland (over 5 million in 2018, Fig. 6), but has a relatively small number of bathing areas. Similarly, the Ślaskie Voivodeship has over 4.5 million inhabitants and only 16 available bathing areas in 2018 (see: Fig. 6).

With each subsequent year from 2012 to 2017 , the number of inland bathing areas (facilities by the lakes and rivers) decreased, in contrast to the number of sea bathing areas, which by 2017 were 10 more than in 2012 (see: Fig. 4). However, a significant change in the number of bathing areas in both inland surface and coastal waters took place only after the introduction of restrictions on the length of the bathing season for sites occasionally used for bathing ( 30 days in a calendar year). The increase in the number of bathing areas in 2018 and 2019 was accompanied by a change in the percentage ratio of the inland to sea bathing waters, which in 2018 was: $70 \%$ to $30 \%$ (see: Fig. 5). In 2018, the largest number of bathing areas was in the Pomeranian (105) and West Pomeranian (104) Voivodeships. The least bathing areas were in the Podkarpackie (7) and Świętokrzyskie (8) Voivodeships, and 9 were in the Lesser Poland Voivodship, which is a significant change compared to 2011, when there were no bathing beaches (see: Fig. 6). The most inland bathing waters were in 2018 in the following voivodeships: Greater Poland (67), Warmian-Masurian (34), West Pomeranian (33) (GIS 2019a) (see: Fig. 6). The analysis of water
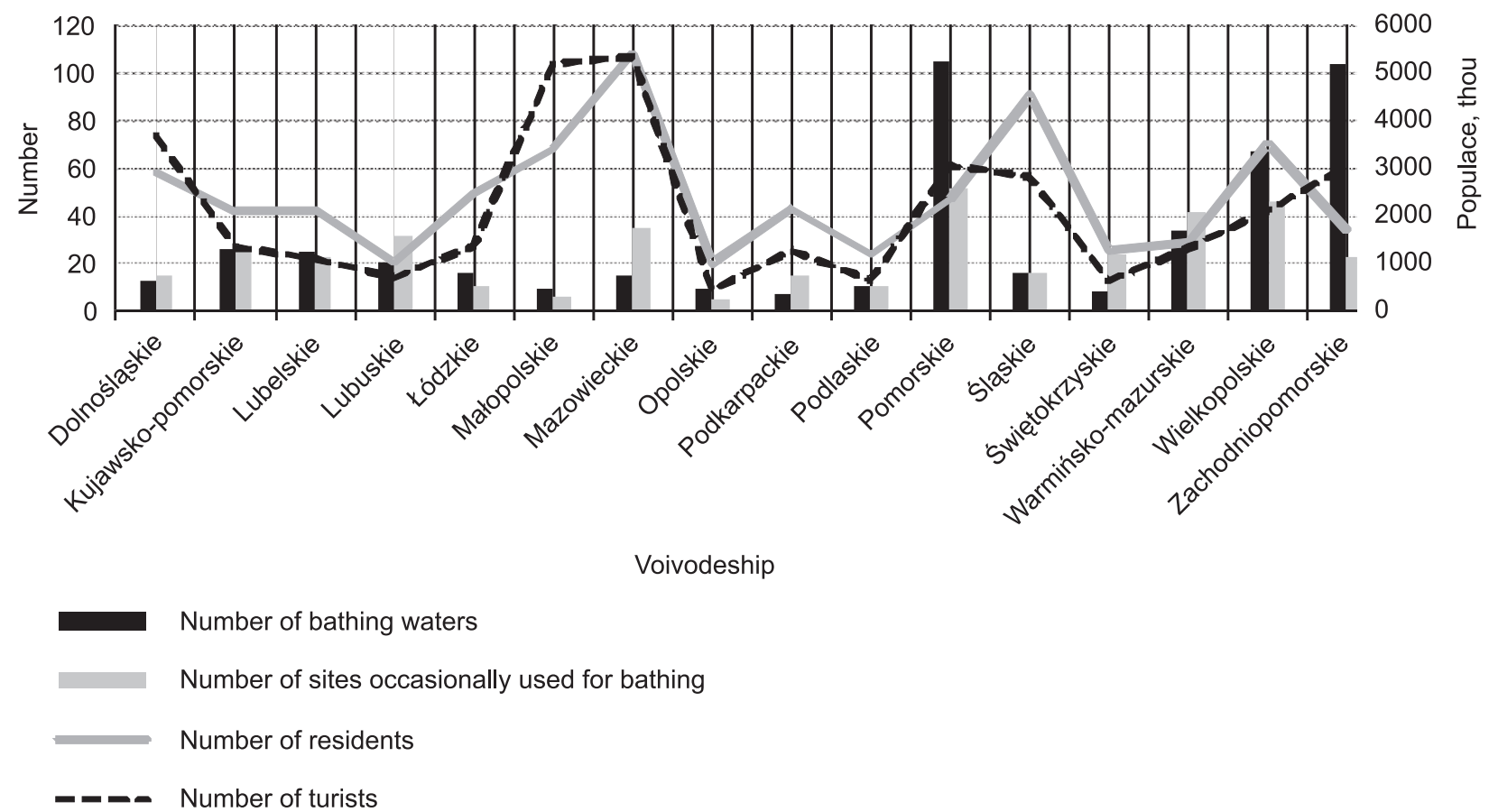

Fig.6. Number of bathing waters and sites occasionally used for bathing and the number of residents and tourists in individual voivodeships in Poland in 2018

Source: own study, according to the Chief Sanitary Inspectorate reports (2019a), the Statistics Poland (GUS 2019a, 2020b) 
body type where bathing areas were located in Poland shows that the majority of facilities organized in 2011 were by lakes (about $50 \%$ ), by coastal and transitional waters (about $40 \%$ ), and the least by rivers (about $10 \%)$. In 2018, the number of bathing areas increased at all waters (see: Table 3, Fig. 5), however their percentage distribution in relation to the total number of bathing areas changed and amounted to: $58 \%$ of lakes; $12 \%$ of rivers; $30 \%$ of coastal and transitional waters (GIS 2019a).

Similarly to bathing areas, sites occasionally used for bathing were too organized both by inland and sea waters. In 2018, the most of these sites were set up in the Pomeranian (51), Greater Poland (46), Warmian-Masurian (41), Masovian (35), Kuyavian-Pomeranian (27) voivodeships and the least in Opolskie (5), while the Lesser Poland voivodeship had 6, with additional 9 bathing areas (GIS 2019a) (see: Fig. 6).

\section{Bathing water quality assessment}

In 2010, the bathing water quality (organised and unorganised) was assessed by the State Sanitary Inspection on the basis of the Regulation of the Minister of Health of 16th October 2002 on the requirements to be met by bathing waters (Journal of Laws No. 183, item 1530). This regulation was consistent with the EU Directive of 8th December 1975 concerning bath- ing water quality (76/160/EEC) (GIS 2009), which preceded the 2006 Directive. A significant group of bathing areas in Poland in 2010 were unsuitable for water quality (see: Fig. 7). According to the Chief Sanitary Inspectorate (GIS) (2010), the main reason for this was unregulated wastewater management, including an inflow of pollutants to water bodies, on which bathing waters are located, so it was impossible to improve water quality permanently with uncoordinated and locally undertaken remedial actions. Mostly the physicochemical indicators were breeched, microbiological indicators and cyanobacteria blooms occurred to a lesser extent. It should be emphasized that 2010 in the analysed period of 2010-2018 in Poland differed significantly from other years in terms of hydrometeorological conditions (PSHM Bulletin 2018). The year 2010 was cool in regard to thermal classification (Climate Monitoring Bulletin of Poland 2010). In terms of annual rainfall, over $60 \%$ of reference meteorological stations registered it as very humid, and for the rest it was damp and even extremely humid (30\% of the stations) (PSHM Bulletin 2018). Also 2010 is classified as wet (see: Table 4) in respect to water abundance - the total outflow by Polish rivers was $86.9 \mathrm{~km}^{3}$ (with the average for the years 1951-2017 equal to $\left.60.4 \mathrm{~km}^{3}\right)$. In the frequency distribution in the 1951-2018 period, which contains 68 elements

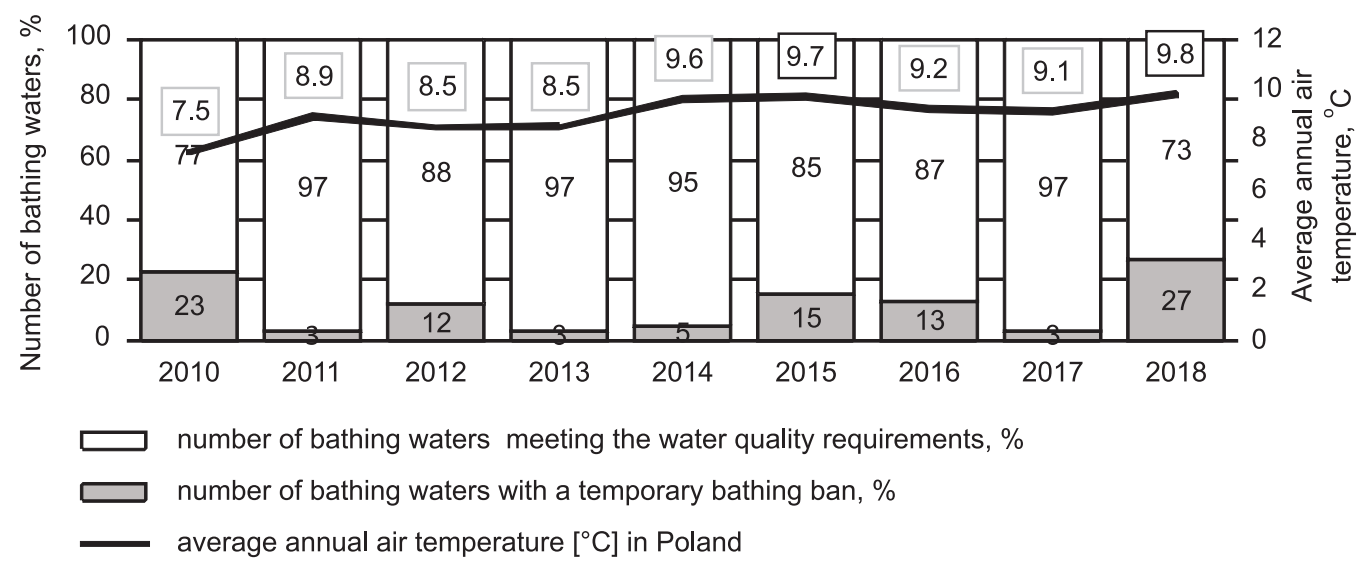

Fig. 7. Percentage ratio of both the number of bathing waters meeting water quality requirements and the number of bathing waters with a temporary bathing ban to the total number of bathing waters in the period of 2010-2018, against the background of the average annual air temperature in Poland

Source: own study, according to the Chief Sanitary Inspectorate reports (2010-2019a), Climate Monitoring Bulletin of Poland (2010-2018) 
Table 4. Assessment of water abundance and thermal conditions in the period of 2010-2018 in Poland in hydrological years (water abundance) and in calendar years (thermal conditions) (according to PSHM Bulletin 2018, Climate Monitoring Bulletin of Poland 2010-2018)

\begin{tabular}{cccccccccc}
\hline Year & 2010 & 2011 & 2012 & 2013 & 2014 & 2015 & 2016 & 2017 & 2018 \\
\hline $\begin{array}{c}\text { Water } \\
\text { abundance }\end{array}$ & wet & wet & dry & normal & normal & dry & dry & normal & Normal \\
\hline $\begin{array}{c}\text { Thermal } \\
\text { classification }\end{array}$ & cool & $\begin{array}{c}\text { very } \\
\text { warm }\end{array}$ & warm & warm & $\begin{array}{c}\text { extremely } \\
\text { warm }\end{array}$ & $\begin{array}{c}\text { extremely } \\
\text { warm }\end{array}$ & $\begin{array}{c}\text { anomalously } \\
\text { warm }\end{array}$ & warm & $\begin{array}{c}\text { extremely } \\
\text { warm }\end{array}$ \\
\hline
\end{tabular}

(the years were put in order of increasing total annual outflow of Poland's rivers), 2010 ranks 66 th. The flood that occurred in Poland in the second half of May 2010 was the largest for 160 years. In the result of floods, waters that were in contact with soils from the catchment area, household wastewater or municipal waste could have been a source of pathogenic microorganisms (Prądecka et al., 2019). Studies by Ślusarczyk and Czaplicka-Kotas (2012) show that floods affect in a characteristic way the distribution of water quality indicators regardless of the season and time.

In the subsequent years of the 2010-2018 period under review (GIS (2020) report on the sanitary condition of Poland in 2019 will be published at the beginning of 2020) 2018 had the largest number of bathing areas with a temporary bathing ban (see: Fig. 7). This year the authorities of the State Sanitary Inspection issued a total of 2,702 assessments, including: 2,472 assessments of the suitability of bathing water for 483 bathing areas; 275 ratings on a temporary bathing ban for 128 bathing sites - mainly due to excessive cyanobacteria blooms $(85 \%)$ or exceeding microbiological parameters (15\%) (GIS, 2019a). The assessments for earlier years 2007-2009 presented by Skotak et al. (2012) show that nearly a quarter of all bathing bans in Poland in the discussed period were associated with cyanobacteria blooms. This situation concerned every fifth bathing beach located on a dam or reservoir and every tenth on the Baltic Sea. The average duration of a bathing ban due to cyanobacteria blooms in sea bathing areas did not exceed a week, and in the case of facilities organized by lakes and reservoirs it was longer, about a month on average. As part of the supervision of water quality, as in previous years, before the introduction of the provisions of the bathing direc- tive in 2006, both bathing organizers and bodies of the State Sanitary Inspection pay special attention to cyanobacteria blooms. Control of cyanobacteria is based on visual monitoring of water, its colour, suspension and turbidity (GIS, 2013).

Bathing season in 2018 was exceptional in terms of the number of ratings issued on a temporary bathing ban due to excessive cyanobacteria blooms (see: Fig. 8, Fig. 9), which was particularly noticeable for tourists resting on the Baltic Sea (GIS, 2019a), especially in Gdańsk Bay (see: Fig. 9b). The percentage share of the number of bathing waters in which excessive cyanobacteria blooms were found, was divided into categories: 61\% (66) of sea bathing waters; $32 \%$ (35) bathing beaches on lakes; $7 \%$ (8) bathing beaches on rivers (GIS, 2019a). According to the PSHM-PIB Bulletin (2018), the average annual temperature in Poland in 2018 was $9.8^{\circ} \mathrm{C}$ (see: Fig. 7), that is $2.2^{\circ} \mathrm{C}$ higher than the long-term norm of 1971-2000, and summer throughout Poland was extremely warm.

Pac's (2012) research on the conditions of occurrence and reproduction of cyanobacteria indicates that the factors influencing cyanobacteria blooms are an increase in the content of nutrients in a reservoir and a longer period of warm and sunny weather. Also, the rate of cyanobacteria proliferation is closely related to the temperature and length of solar day. Predominance of toxic strains of cyanobacteria over non-toxic depends on the length and availability of light during spring and summer (Gehringer and Wannicke, 2014). According to Gehringer and Wannicke (2014), an increased frequency of harmful cyanobacteria blooms is observed in freshwater and marine ecosystems. A further rise of air temperature and $\mathrm{CO}_{2}$ concentrations 


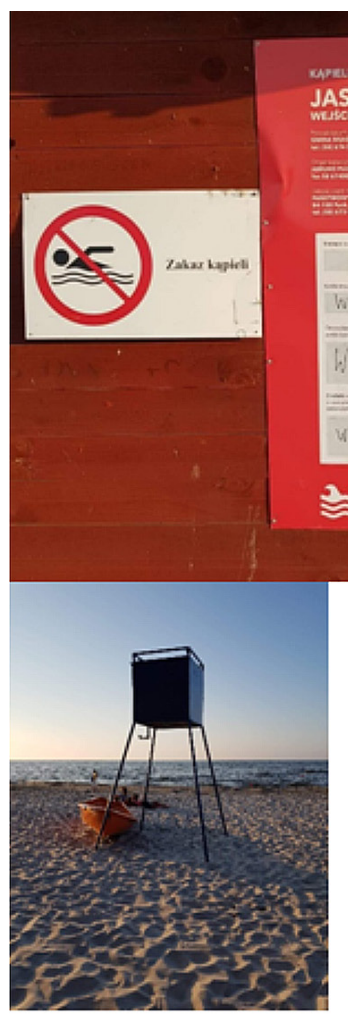

a) Poland

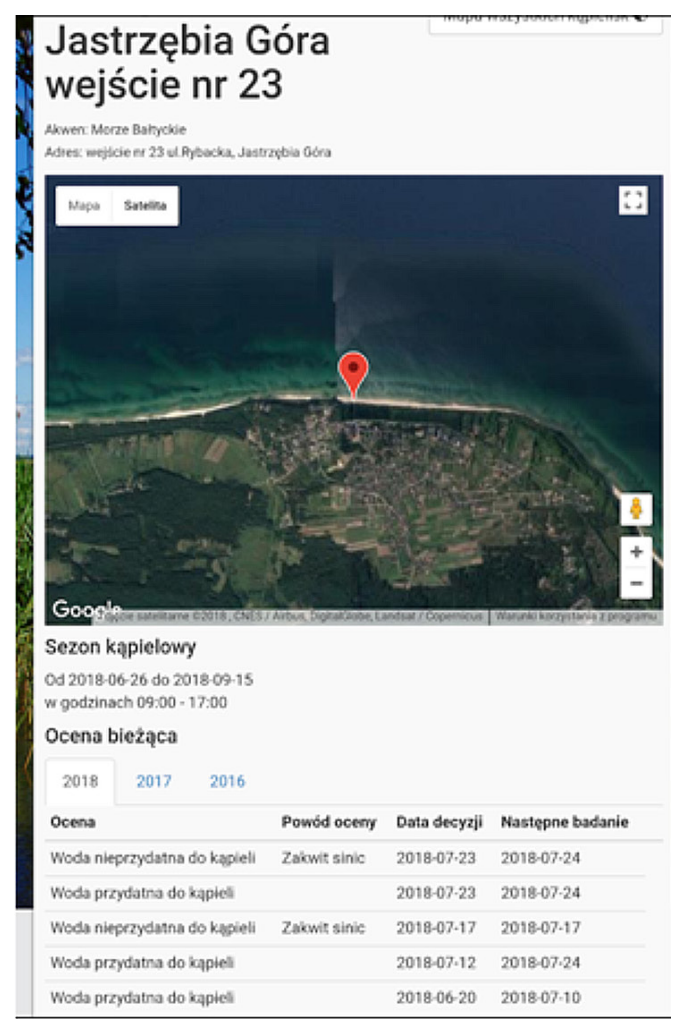

b) Gdańsk Bay (Poland)

Fig.8. The Jastrzębia Góra bathing area, cyanobacteria blooms, July 2018
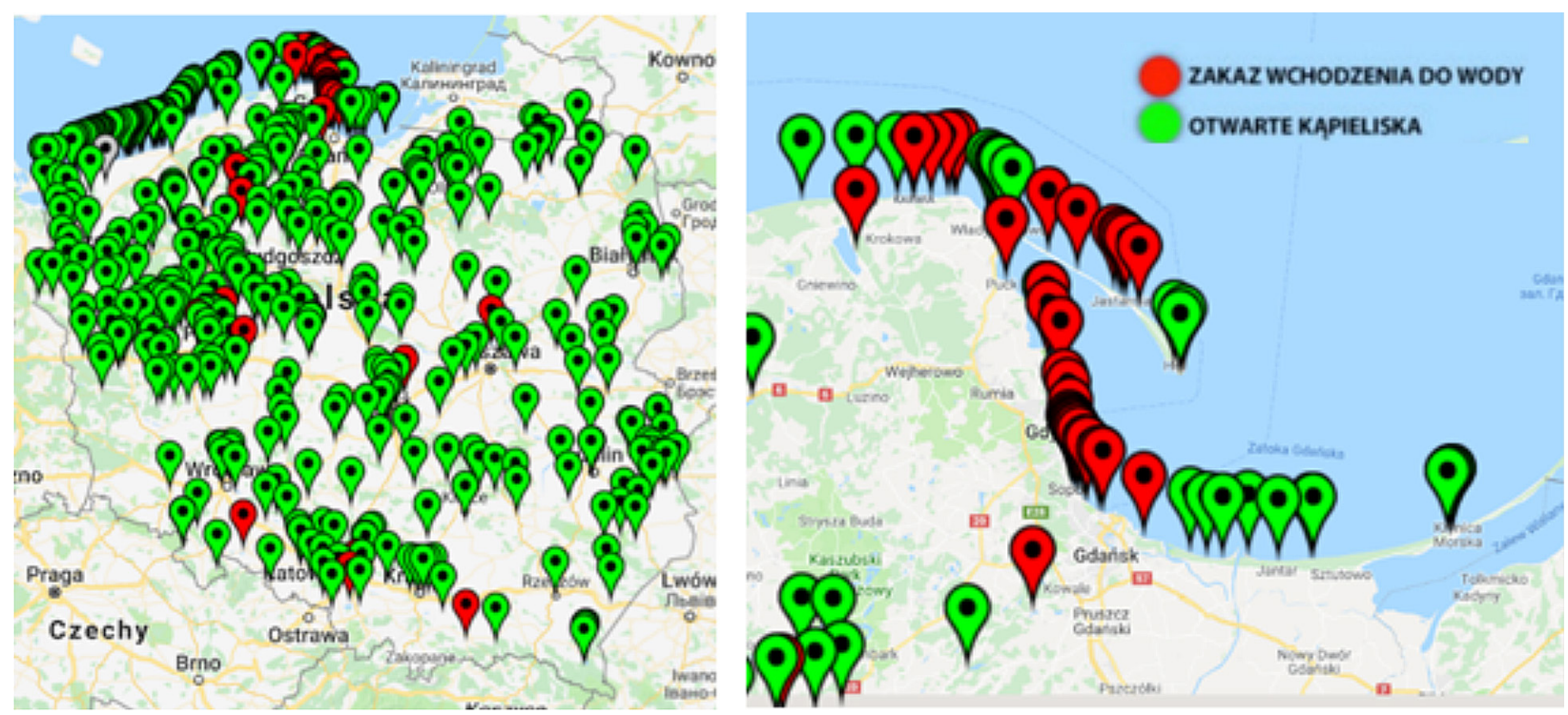

Fig.9. Map of bathing waters with a temporary bathing ban (red marks) on July 31, 2018 in Poland, Gdańsk Bay in particular (according to https://sk.gis.gov.pl of July 31, 2018) 
in the atmosphere would favour cyanobacteria growth and development and could prompt their expansion. Studies by Kobos et al. (2012) on the distribution of cyanobacteria genera and species in Polish reservoirs together with the assessment of frequency of toxins produced showed that the presence of cyanotoxins has been documented in $75 \%$ of the examined freshwater in Poland, with some cases very high concentration of toxins. Cyanobacteria communities in Poland consist mainly of Planktothrix, Aphanizomenon, Microcystis and Dolichospermum, which corresponds to a typical structure of cyanobacteria communities in many eutrophied waters in Europe.

Pac (2012) also reports that eutrophication is the main cause of cyanobacteria in reservoirs, which can be of natural or anthropogenic origin. The eutrophication process in water reservoirs may be intensified by a water deficit, which accelerates a mass development of cyanobacteria and forces a bathing ban (Bańkowska and Wasilewicz, 2008). The seasonal number of indicator bacteria populations in water reservoirs depends on air temperature - with its lowering the number regularly decreases (Policht-Latawiec et al., 2017). Also, apart from thermal conditions, an intensive use of bathing waters has a significant impact on an increase in the number of indicator microorganisms (Chmiel and Maciagg, 2010). Rainwater runoff, which carries bacteria washed out of the atmosphere or from communication routes (Frąk and Nestorowicz, 2009), also contributes to the deterioration of water sanitary state. The quality of surface water is also negatively affected by intensive fish farming in flow reservoirs (Moniewski and Stolarska, 2007).

The results of tests on the number of sanitary indicator bacteria and the date of cyanobacteria blooms for selected five bathing sites located in the Baltic Sea and Gdańsk Bay, from the period 2016-2019, are presented in Figure 10. On this basis the State Sanitary Inspection issued current assessments of bathing water quality during the last four bathing seasons. Indicator bacteria are an important microbiological parameter determining the sanitary conditions of aquatic ecosystems. Among them, faecal bacteria such as Escherichia coli (E. coli) play a special role, as they indicate a presence of fresh domestic sewage in bathing waters (Kubera and Małecka-Adamowicz, 2017). In 2016-2019, only in the Sarbinowo bathing waters the number of E. coli (10687) exceeded the limit value $\leq 1000 \mathrm{cfu} / 100 \mathrm{ml}$ or MPN/100ml (Regulation of the Minister of Health of 17th January 2019 on the supervision of bathing water quality and sites occasionally used for bathing (Journal of Laws, item 255) on 25th August 2016. This pollution was not taken into account when classifying bathing water quality due to its short duration (Regulation of the Minister of Health of 17th January 2019). In the studied period 2016-2019, the Grzybowo and Gdańsk Stogi bathing areas showed the smallest number of $\mathrm{E}$. coli bacteria.

The number of Enterococci bacteria should not exceed $400 \mathrm{cfu} / 100 \mathrm{ml}$ or MPN100ml in bathing waters according to the Regulation of the Minister of Health from 2019. The number of these bacteria in each of the five bathing sites selected for analysis in summers from 2016 to 2019 was within the limit values, and in some periods enterococci were not detected.

In 2016-2019, the main reason making these bathing waters unsuitable were cyanobacteria blooms. Especially in 2018, high temperature favoured an excessive proliferation of cyanobacteria, as well as lack of intense mixing of water due to windless weather. Significant amounts of nitrogen and phosphorus (GIS, 2019a) are also factors conducing cyanobacteria blooms in the Baltic Sea. Cyanobacteria blooms were observed in the bathing waters in Jastrzębia Góra, Gdańsk Stogi and Stegna. The most of toxic cyanobacteria blooms were recorded in Jastrzębia Góra, almost every year except 2017. While, the Gdańsk Stogi bathing area had blooms only in July in 2018, and in Stegna only in July 2019. Both the Grzybowo and Sarbinowo bathing areas had no cyanobacteria blooms in all of the examined four years, which may be caused primarily by their location on the Baltic Sea coast near Kołobrzeg. These bathing areas (see: Fig. 2 Sarbinowo bathing beach, 21st August 2015, water temperature $8^{\circ} \mathrm{C}$ ) are more often exposed to another phenomenon that leads to a temporary bathing ban - upwelling. In the result of this process, surface waters are pushed back from the shore, and in their place usually colder waters from greater depths are brought to the surface (Ciupiał and Wochna, 2016). According to Krężel et al. (2005). Polish coastal waters of the southern Baltic are characterized by the frequent occurrence of coastal upwelling. There are 


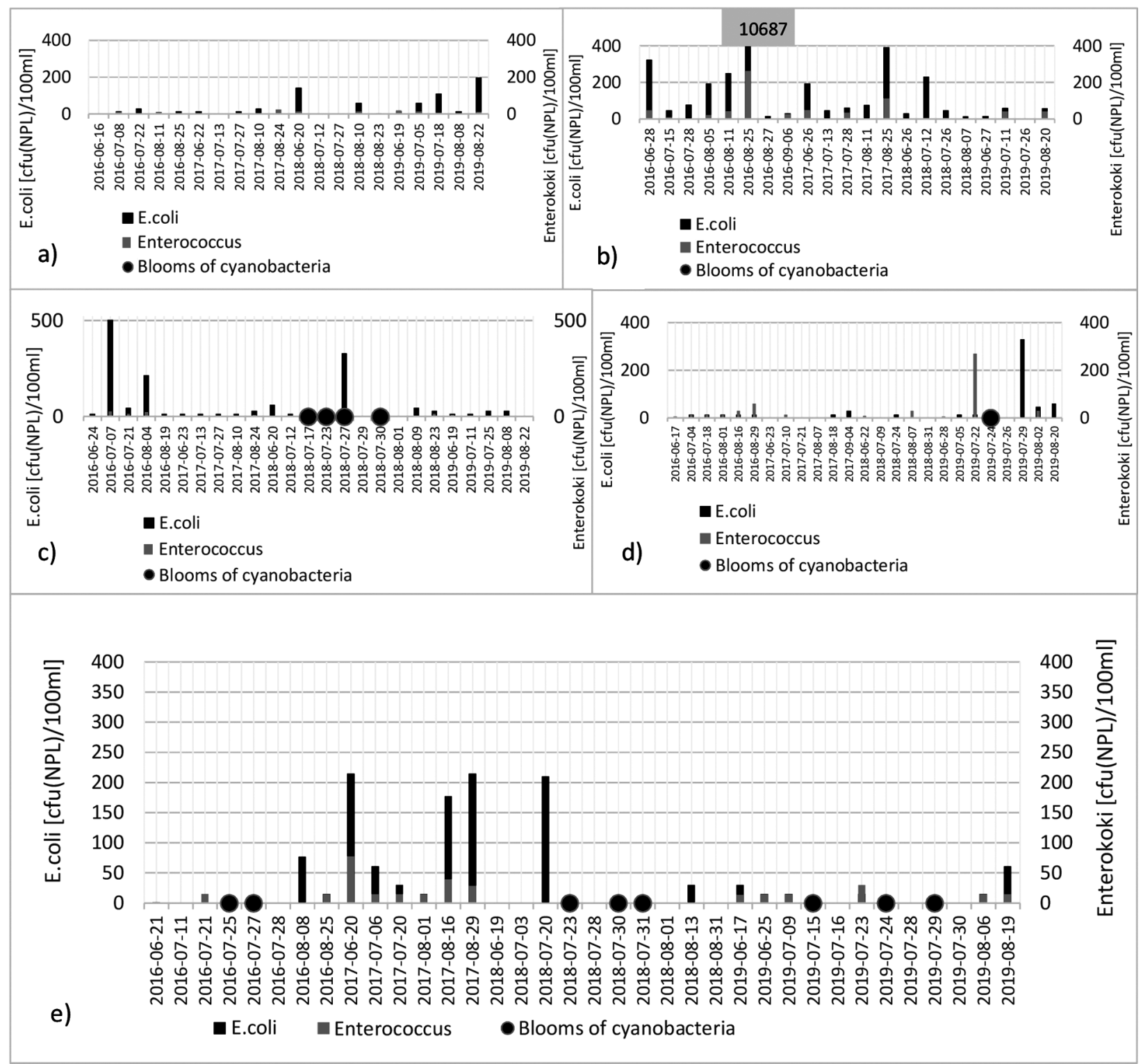

Fig. 10. Number of bacteria indicating the sanitary state and the occurrence of cyanobacteria blooms in bathing waters: Grzybowo (a), Sarbinowo (b), Jastrzębia Góra (c), Stegna (d), Gdańsk Stogi (e) in the period of 2016-2019 (own study according to https://sk.gis.gov.pl)

three upwelling zones in the vicinity of the Baltic Sea in Poland: Helski, Łebski and Kołobrzeski (Ciupiał and Wochna, 2016).

None of the studied bathing waters were classified below 'sufficient'. The bathing beaches in Stegna and Grzybowo (except 2015) were excellent, in Jastrzębia Góra and Stogi - good, and sufficient in Sarbinowo (sk.gis.gov.pl).

\section{Water quality classification}

Bathing areas reported for the 2011 bathing season were subject for the first time to a four-year assessment, which after the 2014 bathing season ended with their quality classified as 'excellent', 'good', 'sufficient' or 'poor' (GIS, 2014). The water quality classification was done for 165 bathing areas out of 201 organized in 2014, due to the availability of full 
sets of water quality data necessary to assign to individual classes. According to the classification, as many as $70 \%$ of bathing areas had excellent water quality, and $10 \%$ was sufficient, with only one bathing area unsatisfactory. Four years later, in 2018, the number of bathing areas subject to a 4-year evaluation was similar -182 . The number of bathing areas without any assessment was 1.5 times higher (301 bathing areas), and this was due to a rise in the number of new bathing areas organized in 2018 compared to previous years, as a result of changes in the Polish legal order (see: Table 5). In 2018, similarly to 2014, over $70 \%$ of bathing areas showed excellent water quality, about $10 \%$ obtained a satisfactory grade. Only 3 bathing areas organized in inland waters were rated poor, which is about $2 \%$ of all assessed bathing waters (see: Table 5).

\section{Bathing water quality in Poland against the background of the European Community countries}

Poland, like other EU countries, is obliged to report on the state of water quality in national bathing waters to the European Commission by $31^{\text {st }}$ December of each year. The reporting obligation results from the implementation of the provisions of the 2006
Directive. A similar obligation was in the provisions of the previous directive from 1976. The European Commission is required to publish annual summary reports on the quality of bathing waters in the EU. Poland is preparing an appropriate summary of information related to bathing water quality since 2005 , i.e. the first full year of participation in the Community (accession to the group of EU countries took place on $1^{\text {st }}$ May 2004).

The only criterion for selecting bathing areas that should be reported to the European Commission, in accordance with the provisions of Directives 76/160/ EEC and 2006/7/EC, is a large (significant) number of bathers during the bathing season. This means that the European Commission does not clearly specify the criteria, leaving the issue of selection of bathing areas to be reported to member states. That is why Poland in 2010 prepared for the European Commission information on 316 bathing areas (for which the number of bathers in the bathing season determined by the Sanitary Inspection Stations was significant, compliance of the sampling frequency at the area of the bathing area in accordance with EU requirements and Polish law, the estimated minimum time operation of a given bathing area not less than 3 years),

Table 5. Results of classification of bathing water quality between 2014 and 2018 in Poland and the percentage of bathing waters with a certain water quality in the total number of bathing waters assessed in individual years of the 2014-2018 period in Poland

\begin{tabular}{|c|c|c|c|c|c|c|c|}
\hline \multirow{2}{*}{ Year } & \multicolumn{3}{|c|}{ Number of bathing areas } & \multirow{2}{*}{$\begin{array}{l}\overrightarrow{0} \\
\stackrel{\vec{D}}{\vec{e}} \\
\text { 离 }\end{array}$} & \multirow{2}{*}{$\begin{array}{l}\overrightarrow{0} \\
0 \\
0\end{array}$} & \multirow{2}{*}{ 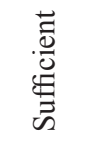 } & \multirow{2}{*}{ 。̈ } \\
\hline & Organised & Classified & Not classified & & & & \\
\hline 2014 & 201 & $\begin{array}{c}165 \\
100 \%\end{array}$ & 36 & $\begin{array}{c}114 \\
69 \%\end{array}$ & $\begin{array}{c}33 \\
20 \%\end{array}$ & $\begin{array}{c}17 \\
10 \%\end{array}$ & $\begin{array}{c}1 \\
1 \%\end{array}$ \\
\hline 2015 & 197 & $\begin{array}{c}181 \\
100 \%\end{array}$ & 16 & $\begin{array}{c}120 \\
66 \%\end{array}$ & $\begin{array}{c}43 \\
24 \%\end{array}$ & $\begin{array}{c}16 \\
9 \%\end{array}$ & $\begin{array}{c}2 \\
1 \%\end{array}$ \\
\hline 2016 & 201 & $\begin{array}{c}182 \\
100 \%\end{array}$ & 20 & $\begin{array}{c}133 \\
73 \%\end{array}$ & $\begin{array}{c}32 \\
17 \%\end{array}$ & $\begin{array}{c}16 \\
9 \%\end{array}$ & $\begin{array}{c}1 \\
1 \%\end{array}$ \\
\hline 2017 & 205 & $\begin{array}{c}182 \\
100 \%\end{array}$ & 22 & $\begin{array}{c}137 \\
75 \%\end{array}$ & $\begin{array}{c}26 \\
14 \%\end{array}$ & $\begin{array}{c}14 \\
8 \%\end{array}$ & $\begin{array}{c}5 \\
3 \%\end{array}$ \\
\hline 2018 & 483 & $\begin{array}{c}182 \\
100 \%\end{array}$ & 301 & $\begin{array}{c}135 \\
74 \%\end{array}$ & $\begin{array}{c}26 \\
14 \%\end{array}$ & $\begin{array}{c}18 \\
10 \%\end{array}$ & $\begin{array}{c}3 \\
2 \%\end{array}$ \\
\hline
\end{tabular}

Source: own study: according to the Chief Sanitary Inspectorate reports (2014-2019a) 


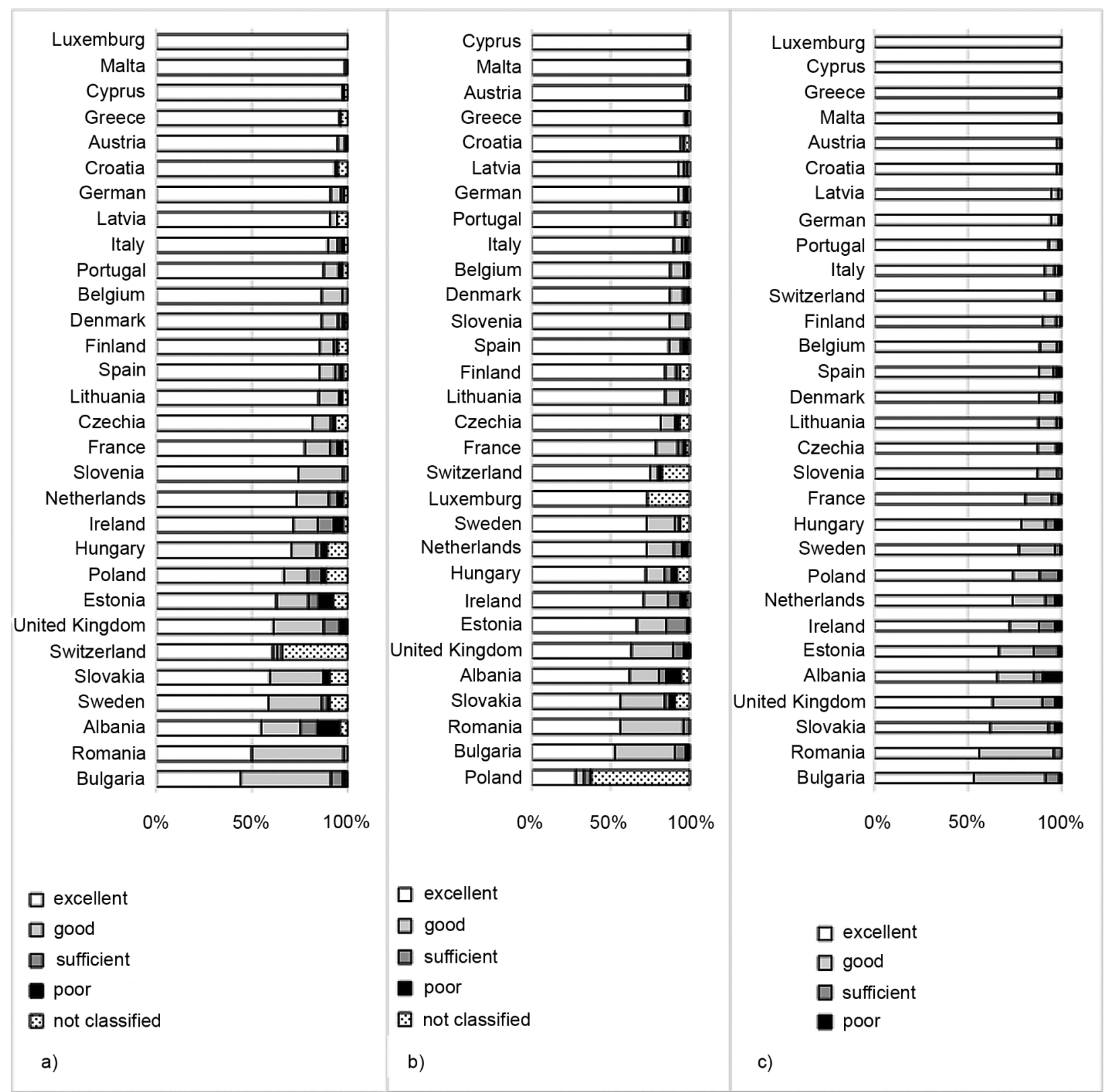

Fig. 11. Classification of European bathing waters a) in 2017 b) in 2018 c) in 2018 in terms of water quality, excluding unclassified bathing waters

Source: own study, according to EEA $(2018,2019)$ 
although there were as many as 1229 in the PIS records (see: Table 3). From 2011, the provisions of Directive 2006/7/EC were in force and Poland reported the state of water quality only in bathing areas organized according to the new guidelines. The reports of the European Commission (EEA 2018) show that the bathing water quality is constantly improving, meaning that over $90 \%$ of bathing areas monitored in the European Union in 2017 met the minimum standards. According to the report (EEA, 2018), in 2017 Poland ranks $22^{\text {nd }}$ on the list of 30 European countries (see: Fig. 11a) in terms of the number of bathing areas with excellent water quality ( $68 \%$ of all bathing areas). It should be clarified here that data from the Community (28 associated countries) and two non-members of the Community are taken into account, i.e. Albania and Switzerland.

The list from the next year (EEA 2019) is interesting, as it shows Poland's drop to the last place in the ranking of European bathing water quality (see: Fig. 11b).

This does not mean a drastic deterioration of water quality, but is only an effect of the adopted methodology of bathing waters assessment. In 2018, due to reporting a large number of new bathing areas to the list (229 new bathing areas were reported, half of all new European bathing waters), there was no four-year quality data string for them. In addition, out of the existing bathing waters, 72 could not yet be assessed due to gaps in data. This gives a total of 301 bathing areas (see:Table 5) without any assessment, which were included in the list. Removing information on unclassified bathing areas puts Poland back in 22nd position in the 2018 list (see: Fig.11c).

Top bathing waters belong to five European Union countries: Luxembourg, Malta, Cyprus, Greece and Austria, where the percentage of bathing areas with excellent water quality is over $95 \%$. The lowest water quality is in three countries: Slovakia, Romania, Bulgaria. Only $52 \%$ of bathing areas in Bulgaria have excellent water quality.

\section{SUMMARY}

Improving water quality and protecting people's health in bathing areas is a key goal set for European Union countries. The implementation of the Directive 2006/7/EC of the European Parliament and of the
Council of 15th February 2006 on the management of bathing water quality has resulted in a number of positive changes in the organization of bathing waters in Poland, especially since the bathing season in 2018. The initiated process of increasing the number of bathing waters with the highest standards is the goal of authorities involved in the organization of bathing areas, in particular commune heads, mayors or city presidents.

In the last, anomalously warm years, the biggest threat to the quality of bathing waters or sites occasionally used for bathing are cyanobacteria blooms. Bathing waters located by stagnant waters (lakes) are particularly sensitive to this phenomenon, where, according to literature, cyanobacteria blooms can persist for up to a month. The new obligations of bathing organizers are numerous and require due attention in the preparation and implementation of internal control of bathing water quality. Errors reported by the authorities of the Supreme Audit Office in 2014 show cases of an insufficient number of water samples taken during a bathing season, which did not allow to assess a given bathing area in terms of water quality. The risk of water sampling by untrained persons is also worrying, as it can disturb actual results of bathing water quality.

The purpose for these changes to the Polish legal order is to achieve a good quality of bathing waters in a four-year assessment, and this goal in the studied period of 2014-2018 was reached for most of the organized bathing areas. Only about $2 \%$ of all bathing areas - located at inland waters - had inadequate water quality. However, compared to other EU countries, according to the latest EEA report (2019) for 2018, we have definitely a smaller number of bathing waters with excellent water quality -22 place out of 28 in the European Commission ranking.

The Directive of 2006 also was meant to put a stronger emphasis on publicising information on bathing water quality. The bathing website created by the Chief Sanitary Inspectorate in Poland fulfils this task, and publicly available messages not only contribute to ensuring the health safety of the bathers, but also serve to raise the health awareness. According to the bodies of the State Sanitary Inspection (GIS, 2018), the online bathing website was visited by more than 800,000 people in 2018 . 


\section{REFERENCES}

Bańkowska, A., Wasilewicz, M. (2008). Przegląd działań realizowanych w celu poprawy stanu Jeziora Zdworskiego. Przegląd Naukowy Inżynieria i Kształtowanie Środowiska, 1, (39), 80-90.

Chmiel, M.J., Maciag, A. (2010). Ocena stanu sanitarnego zbiornika wodnego w Kryspinowie. Nauka Przyr. Technol. 4, 6, 1-8.

Ciupiał, A., Wochna, A. (2016). Upwelling na Morzu Bałtyckim - znaczenie i metody detekcji. Tutoring Gedanensis 1(1) 13-18.

Dyrektywa 76/160/EWG z dnia 8 grudnia 1975 r. dotyczącej jakości wody w kąpieliskach (Dz. Urz. WE L 31 z 05.02.1976. Dz. Urz. UE Polskie wydanie specjalne, rozdz. 15, t. 1, s. 26.). Dyrektywa 2006/7/WE Parlamentu Europejskiego i Rady z dnia 15 lutego 2006 r. dotycząca zarządzania jakością wody w kapieliskach i uchylająca dyrektywę 76/160/EWG (Dz.U. L 64 z 4.3.2006, s. 37).

European Environment Agency (EEA). (2018). Quality of bathing waters 2017.

European Environment Agency (EEA). (2019). Quality of bathing waters 2018.

Frąk, M., Nestorowicz, A. (2009). Ocena stanu sanitarnego wybranych zbiorników wodnych parków miejskich Warszawy. Przegląd Naukowy Inżynieria i Kształtowanie Środowiska. 44, 3-10.

Gehringer, M.M., Wannicke, N. (2014). Climate change and regulation of hepatotoxin production in cyanobacteria. FEMS Microbiology Ecology, 88(1), 1-25.

Główny Inspektorat Sanitarny (GIS). (2010). Stan Sanitarny Kraju w roku 2010.

Główny Inspektorat Sanitarny (GIS). (2011). Zamknięcie sezonu kąpielowego w Polsce w 2011 roku.

Główny Inspektorat Sanitarny (GIS). (2012). Stan Sanitarny Kraju w roku 2012.

Główny Inspektorat Sanitarny (GIS). (2013). Stan Sanitarny Kraju w roku 2013.

Główny Inspektorat Sanitarny (GIS). (2014). Stan Sanitarny Kraju w roku 2014.

Główny Inspektorat Sanitarny (GIS). (2015). Stan Sanitarny Kraju w roku 2015.

Główny Inspektorat Sanitarny (GIS). (2016). Stan Sanitarny Kraju w roku 2016.

Główny Inspektorat Sanitarny (GIS). (2018). Stan Sanitarny Kraju w roku 2017.

Główny Inspektorat Sanitarny (GIS) (2018). Lista miejsc okazjonalnie wykorzystywanych do kąpieli.

Główny Inspektorat Sanitarny (GIS) (2019a). Stan Sanitarny Kraju w roku 2018.
Główny Inspektorat Sanitarny (GIS) (2019b). Lista miejsc okazjonalnie wykorzystywanych do kapieli, (MOWK) stan na dzień 28 sierpnia 2019 r.; https://gis.gov.pl/wpcontent/uploads/2018/07/lista-miejsc-okazjonalnie-wykorzystywanych-do-k\%C4\%85pieli-19.07.2018r.xls; https://gis.gov.pl/wypoczynek/pobieranie-probek-wody -z-kapielisk-i-miejsc-okazjonalnie-wykorzystywanych -do-kapieli/

Główny Inspektorat Sanitarny (GIS). (2020). Stan Sanitarny Kraju w roku 2019 (w przygotowaniu).

Główny Urząd Statystyczny (GUS). (2019a). Rocznik Demograficzny. Warszawa.

Główny Urząd Statystyczny (GUS). (2019b). Turystyka w 2018 roku. Seria 'Analizy statystyczne', Warszawa; http://stat. gov.pl/obszary-tematyczne/kultura-turystyka-sport/

Instytut Meteorologii i Gospodarki Wodnej Państwowy Instytut Badawczy (IMGW-PIB). (2018a). Biuletyn Państwowej Służby Hydrologiczno-Meteorologicznej (Biuletyn PSHM) Rok 2018 nr 13 (202).

Instytut Meteorologii i Gospodarki Wodnej Państwowy Instytut Badawczy (IMGW-PIB). Biuletyn monitoringu klimatu Polski rok 2010, 2011, 2012, 2013, 2014, 2015, 2016, 2017, 2018; http://klimat.pogodynka.pl/pl/biuletyn-monitoring/

Kanownik, W., Kowalik, T. (2008). Walory użytkowe wody rzeki Wilgi w aspekcie jej magazynowania w małym zbiorniku retencyjnym. Acta Sci. Pol., Formatio Circumiectus 7 (3), 23-31.

Kobos, J., Błaszczyk, A., Hohlfeld, N., Toruńska-Sitarz, A., Krakowiak, A., Hebel, A., Sutryk, K., Grabowska, M., Toporowska, M., Kokociński, M., Messyasz, B., Rybak, A., Napiórkowska-Krzebietke, A., Nawrocka, L., Pełechata, A., Budzyńska, A., Zagajewski, P., Mazur -Marzec, H. (2013). Cyanobacteria and cyanotoxins in Polish freshwater bodies. Oceanological and Hydrobiological Studies 42(4), 358-378.

Krężel, A., Szymanek, L., Kozłowski, Ł., Szymelfenig, M. (2005). Influence of coastal upwelling on chlorophyll a concentration in the surface water along the Polish coast of the Baltic Sea. Oceanologia, 47 (4), 433-452.

Król, Z.J. (2019). Odpowiedź na interpelację nr 25653 w sprawie kąpielisk i miejsc okazjonalnie wykorzystywanych do kapieli w woj. kujawsko-pomorskim, Sejm Rzeczypospolitej Polskiej, VIII kadencja; http://www. sejm.gov.pl/Sejm8.nsf/InterpelacjaTresc.xsp?key=B9MGR2\&view=1

Kubera, Ł,. Małecka-Adamowicz, M. (2017). Ocena stanu sanitarno-bakteriologicznego zbiornika wodnego 'Balaton’ zlokalizowanego w centrum Bydgoszczy. Woda-Środowisko-Obszary Wiejskie. 17. 1, (57), 63-73. 
Moniewski, P., Stolarska, M. (2007). Wpływ naturalnych i antropogenicznych czynników na podstawowe charakterystyki fizykochemiczne wody w małej zlewni strefy podmiejskiej Łodzi. Woda-Środowisko-Obszary Wiejskie. 7, 1 (19), 105-122.

Najwyższa Izba Kontroli (NIK). (2014). Informacja o wynikach kontroli 'organizacja i utrzymanie kapielisk oraz miejsc wykorzystywanych do kapieli', Departament Środowiska, KSI-4101-002-00/2014 Nr ewid. 188/2014/P/14/056/KSI; https:/www.n0ik.gov.pl/kontrole/P/14/056/LOL/

Pac, M. (2012). Sinice (cyanobacteria) w środowisku słodkowodnym. Woda-Środowisko-Obszary Wiejskie (VII-IX), 12,3(39), 187-195.

Policht-Latawiec, A., Żarnowiec, W., Perec-Krupa, Z. (2017). Zanieczyszczenia bakteriologiczne w ocenie jakości wody w zbiorniku Besko przeznaczonej do zbiorowego zaopatrzenia ludności. Woda-Środowisko-Obszary Wiejskie. 17, 4 (60), 111-128.

Prędecka, A., Górska, E.B., Russel, S., Augustynowicz, J. (2019). Wpływ powodzi na stan sanitarny wody z rzeki Wisły w rejonie dzielnicy Nowodwory w Warszawie. Woda-Środowisko-Obszary Wiejskie. 19, 1(65), 67-76.

Rozporządzenie Ministra Zdrowia z dnia 16 października 2002 r. w sprawie wymagań, jakim powinna odpowiadać woda w kapieliskach. Dz. U. z 2002 r. Nr 183 poz. 1530.

Rozporządzenie Ministra Środowiska (Rozporządzenie Ministra Środowiska z dnia 2 lutego 2011 r. w sprawie profilu wody w kapielisku (Dz. U. Nr 36, poz. 191).

Rozporządzenie Ministra Zdrowia z dnia 8 kwietnia 2011 r. w sprawie prowadzenia nadzoru nad jakością wody w kąpielisku i miejscu wykorzystywanym do kapieli (Dz. U. Nr 86, poz. 478).

Rozporządzenie Ministra Zdrowia z dnia 28 kwietnia 2011 r. (Dz. U. Nr 91, poz. 527) w sprawie ewidencji kąpielisk oraz sposobu oznakowania kąpielisk i miejsc wykorzystywanych do kapieli.

Rozporządzenie Ministra Zdrowia z dnia 21 grudnia 2018 r. w sprawie ewidencji oraz sposobu oznakowania kappielisk i miejsc okazjonalnie wykorzystywanych do kapieli (Dz. U. poz. 2476).

Rozporządzenie Ministra Zdrowia z dnia 17 stycznia 2019 r. w sprawie nadzoru nad jakością wody w kapielisku i miejscu okazjonalnie wykorzystywanym do kapieli (Dz. U. poz. 255).

Skotak, K., Bratkowski, J., Jamsheer-Bratkowska, M., Stankiewicz, A., Maziarka, D. (2012). Ocena wpływu zakwitów sinic na jakość wody w kapieliskach w Polsce, Medycyna Środowiskowa - Environmental Medicine, $15,4,71-79$.

Skotak K., Bratkowski J., Maziarka D., Jamsheer-Bratkowska M. (2012). Nowe zasady zarządzania jakością wody w kapieliskach. Przegl. Epidemiol. 66, 357-365.

Ślusarczyk, Z, Czaplicka-Kotas, A. (2012). Wpływ powodzi w roku 2010 na jakość wód Zbiornika Goczałkowice. Czasopismo Techniczne,109, 2-Ś., 261-270.

Ustawa z dnia 4 marca 2010r. (Dz. U. Nr 44 poz. 253) o zmianie ustawy Prawo wodne z dnia 18 lipca $2001 \mathrm{r}$. (Dz. U. 2005r. Nr 239, poz. 2019).

Ustawa z dnia 20 lipca 2017 r. Prawo wodne (Dz. U. z 2018 poz. 2268 z 2019 r. poz. $125,534,1495,2170)$.

Wojewódzka Stacja Sanitarno-Epidemiologiczna w Szczecinie (WSSE SZCZECIN). (2016). Nadzór nad kąpieliskami. Szczecin, 25 kwietnia 2016 r. http://www. bezpieczenstwo.wzp.pl/sites/default/files/nadzor_i_klasyfikacja_wody.pdf

Zimoch, I., Paciej, J. (2013). Znaczenie kontroli jakości wód powierzchniowych wykorzystywanych do rekreacji na przykładzie województwa śląskiego. Ochrona Środowiska, 35, 2.

\section{KĄPIELISKA W POLSCE - PROBLEMATYKA ORGANIZACJI I NADZORU KĄPIELISK W ŚWIETLE ZMIAN W PRAWIE WODNYM}

\section{ABSTRAKT}

\section{Cel pracy}

Celem pracy jest ocena zmian w organizacji i w nadzorze nad kąpieliskami i miejscami wykorzystywanymi do kąpieli w Polsce, jakie zaszły po wdrożeniu do prawodawstwa polskiego dyrektywy 2006/7/WE.

\section{Materiał i metody}

Wykorzystano akty prawne publikowane przez Sejm RP w Internetowym Systemie Aktów Prawnych oraz coroczne raporty Głównego Inspektoratu Środowiska na temat stanu sanitarnego kraju i dane zamieszczone w serwisie GIS i serwisie kąpieliskowym (sk.gis.gov.pl). Analiza liczebności kapielisk obejmuje okres 
2010-2019, natomiast jakość wody w kapieliskach została przeanalizowana w okresie 2014-2018, Do analiz jakości nie włączono roku 2019 z uwagi na niedostępność danych.

Pod względem jakości najwięcej ocen o nieprzydatności wody do kąpieli w latach 2011-2018 było wydawanych ze względu na zakwity sinic (w 2018 najwięcej). Najczęściej to konsekwencja podwyższonej trofii wód, która jest wypadkową warunków meteorologicznych (upalne lata, intensywne opady), hydrologicznych (susze, powodzie), zdarzeń losowych (awarie oczyszczalni) jak i zmian klimatycznych. Ocena stanu wód przeprowadzona w 2018 roku (będąca średnią z lat 2015-2018) podobnie do oceny z roku 2014 (średnia z okresu 2011-2014) pozwoliła na ustalenie, iż ponad 70\% kapielisk uzyskało doskonałą jakość wody, około $10 \%$ uzyskało ocenę dostateczną i jedynie 3 kąpieliska śródlądowe (1\%) uzyskały ocenę niedostateczną. Według danych z 2018 roku Polska klasyfikuje się na 22 miejscu w UE pod względem liczby kąpielisk o doskonałej jakości wody. Pomimo stale rosnącej tendencji poprawy jakości wody w kąpieliskach na tle pozostałych krajów UE, do średniej europejskiej wynoszącej 85\% kąpielisk z doskonałą jakością wody jeszcze dużo nam brakuje.

Słowa kluczowe: jakość wody, prawo wodne, dyrektywa 2006/7/WE, kapielisko 